\title{
Dental Whitening
}

National Cancer Institute

\section{Source}

National Cancer Institute. Dental Whitening. NCI Thesaurus. Code C94591.

A process that employs special bleaching agents for restoring the color of teeth. 